http://ejtr.vumk.eu

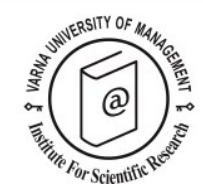

\title{
The influence of risk perception on destination choice processes
}

\author{
Marion Karl ${ }^{1}$
}

Received: 29/06/2017

\begin{abstract}
${ }^{1}$ LMU Munich, Department of Geography. Address: Luisenstrasse 37, 80333 München. Phone: 0049892180 4039. E-mail: marion.karl@Imu.de
\end{abstract}

Supervisors: Prof. Dr. Jürgen Schmude and Prof. Dr. Henrike Rau

Institution awarding the Ph. D. Degree: LMU Munich, Department of Geography

Date of defence: 24/05/2017

(C) 2018 Varna University of Management. All rights reserved

Citation: Karl, M. (2018). The influence of risk perception on destination choice processes. Doctoral Dissertation Summary. European Journal of Tourism Research 18, pp. 160-163

\section{Goal and objectives of the dissertation Goal}

Safety and security are basic prerequisites for the positive development of destinations' tourism sectors (Reisinger and Mavondo, 2005). Risk is moreover one of the most influential factors in tourists' travel decisionmaking and mainly influences the decision where to travel (Fuchs and Pizam, 2011). Although past studies agree that risk influences destination choices, the questions during which step of the travel decisionmaking process risk is most relevant and which other determinants play a role, are not yet answered unambiguously. The aim of this doctoral dissertation is therefore to specifically address these aspects to shed light on tourists' travel decision-making and destination choice process in the context of risk.

\section{Objectives}

Three main objectives lead the doctoral dissertation: First, the focus is on destination choice as one of the most important elements of the travel decision (Crouch, Huybers, and
Oppewal, 2016; Fesenmaier and Jeng, 2000). Here, the main objective is to understand how risk influences the hidden processes in tourists' minds which lead to the early rejection or the final choice of a destination. Second, the research concentrates on individual subjective perceptions of risk instead of actual objective risks since these are stronger influencing factors of travel decision-making (Fuchs and Reichel, 2006; Sönmez and Graefe, 1998b, 1998a). The objective is to understand how the perception of particularly physical risk factors and manmade risk categories shape tourists' past and future destination choices. Third, destination choice is seen as a negotiation process between amenities offered by destinations and tourists' needs (Bekk, Sporrle, and Kruse, 2016). This means that destination choices are investigated as an interaction process between tourist and destination characteristics with risk and risk perception on the nexus between those aspects. The objective is to comprehend how varying perceptions of actual risk levels do reflect in the destination choice processes. 


\section{Methodology}

Based on a literature analysis, influencing factors of destination choice and risk perception are identified and a theoretical framework for the empirical analyses is developed (Karl and Schmude, 2017). In order to gain a comprehensive understanding of the topic, research is conducted using a mix of qualitative (i.e., semi-structured interviews, content analysis, group discussions) and quantitative (i.e., surveys, time series analysis) methods as well as considering macro as well as micro level approaches. The macro level analysis uses aggregated data on tourist arrivals to investigate changes in tourist flows and how risk (here: terrorism) can trigger such changes. The micro level analysis is based on several surveys in Munich, Germany between 2013 and 2016 with standardised questionnaires focusing on how risk perception influences individual travel and destination choice behaviour.

\section{Results}

The macro level analysis of tourist flows focusing on the time dimension in the relation between terrorism and tourism shows that high terrorist activity not only influences tourism development directly but also with a time lag of one or two to six months (Karl, Winder, and Bauer, 2016). Terrorist activity furthermore outweighs all other control variables (e.g. economic situation) in the case example Israel. While the macro level analysis confirms that risk has an impact on the result of the destination choice process, the micro level analyses furthermore reveal that risk and risk perception affect the whole destination choice process: Risk perception is one of the reasons why a destination is rejected or selected at key stages of the destination choice process (Karl and Reintinger, 2016; Karl, Reintinger, and Schmude, 2015). Destination characteristics help to understand why certain destinations are more relevant during hypothetical choices at the beginning or realistic choices towards the end of the destination choice process (Karl and Reintinger, 2017). The further investigation of destination choice in the context of risk underlines that both tourist and destination perspectives are relevant for a better understanding of risk and uncertainty in travel decision-making and destination choice behaviour (Karl, 2018).

\section{Theoretical conclusions}

Reflecting the results of the doctoral dissertation, three remarks on past travel decision-making and destination choice theory can be made. First, the travel behaviour sequence (Choi, Lehto, Morrison, and Jang, 2012; Mansfeld, 1992) should be considered as a circular process where experiences that tourists make during their travels influence their future destination choices. Second, destination choice and destination choice behaviour should be seen as a dynamic process which changes during tourists' lives. Especially, general travel experience influences risk perceptions and shapes destination choices as tourists climb the travel career ladder (concept by Ryan, 1998). Another topic of relevance concerning dynamic destination choice is the tourists' life cycle. Changes in the family situation during tourists' lives (e.g. transition from travelling as a couple to travelling with small children) highly affect risk perceptions and destination choice behaviours. Last, destination choices are part of the open system of tourism, meaning that not only changes in tourists lives but also changes in the source market (e.g. economic crisis) or the destination itself (e.g. rise in terrorist activity) will shape tourists' individual destination choices, hence, resulting in new patterns of tourist flows on an aggregated level.

\section{Practical application of the dissertation}

Practical application of the dissertation's results stem, for example, from the tourist typologies which were developed in the micro level analyses (Karl, 2018; Karl et al., 2015). The results show that a strong discrepancy exists between hypothetical and actual destination choice behaviour for most tourist types. This latent demand represents a vast potential for destinations which are interesting for future hypothetical travels but not for actual implemented trips. With the knowledge about different tourist types, destinations can specifically attract tourists who are potentially 
interested but decide not to travel to the destination by explicitly addressing the biased level of perceived risks in regard to actual risks. For example, during this dissertation, one type of tourist was identified who dreams of visiting rather risky destinations in the future but is not (yet) able to fulfil these dreams. Such tourists are still at the beginning of the travel career ladder and have not achieved adequate coping strategies to deal with risky situations which deters them from traveling to some destinations.

\section{Content of the dissertation}

The doctoral dissertation comprises of five research articles and a summary (Karl, 2017) which goes beyond the discussion and conclusion of each article. The content of the summary, including results that are in parts already published in the articles, is structured into five chapters.

\section{Abstract of chapter one \\ (Relevance of the topic)}

Safety and security are key elements for the tourism sector and risk perception is a decisive determinant of tourists' travel decision-making and destination choice behaviours. The high number of past studies dealing with this topic as well as the current (political) developments, for example considering terrorism in Europe, indicate that risk and tourism is not only interesting for tourism research but will continue to be a relevant topic for society.

\section{Abstract of chapter two}

(Theoretical background)

Various theories such as macroeconomic or behaviouristic models, can be applied in research on travel decision-making and destination choices. In particular, set theory (Crompton and Ankomah, 1993; Decrop, 2010; Um and Crompton, 1990) as a theory which allows not only investigating actually chosen destinations but also destinations which have been rejected during the destination choice process offers a useful tool to analyse destination choice in the context of risk.

\section{Abstract of chapter three \\ (Results)}

Risk perception plays a role during the whole destination choice process but is most relevant during the early stages of the decision when tourists do not actively consider alternatives for an actual holiday but dream destinations for hypothetical future trips.

\section{Abstract of chapter four \\ (Case example Israel)}

Travel experience is a highly relevant factor for destination choices in the context of risk. This aspect appears to be particularly important for Israel, a destination associated with high levels of risk, which was taken as a case study in parts of the doctoral dissertation.

\section{Abstract of chapter five \\ (Conclusion)}

Destination choice in the context of risk should be investigated with concepts that allow observing destination choice as circular and dynamic processes as well as part of the open system of tourism. Longitudinal or panel studies where tourists are interviewed before and after a trip to a destination perceived to be risky or qualitative in-depth interviews to extract a more comprehensive travel biography with key experiences that led to changes in the travel behaviours could be appropriate methods to address these issues in further research.

\section{References:}

Bekk, M., M. Sporrle, M., J. Kruse. (2016). The benefits of similarity between tourist and destination personality. Journal of Travel Research, 55 (8), 1008-1021. doi: 10.1177/0047287515606813

Choi, S., X.Y. Lehto, A.M. Morrison, S. Jang. (2012). Structure of travel planning processes and information use patterns. Journal of Travel Research, 51 (1), 26-40. doi: 10.1177/0047287510394191

Crompton, J.L., P.K. Ankomah. (1993). Choice set propositions in destination decisions. Annals of Tourism Research, 20 (3), 461-476. doi: 10.1016/01607383(93)90003-L 
Crouch, G.I., T. Huybers, H. Oppewal. (2016). Inferring Future Vacation Experience Preference from Past Vacation Choice: A Latent Class Analysis. Journal of Travel Research, 55 (5), 574-587. doi: $10.1177 / 0047287514564994$

Decrop, A. (2010). Destination choice sets: An inductive longitudinal approach. Annals of Tourism Research, 37 (1), 93-115. doi: 10.1016/j.annals.2009.08.002

Fesenmaier, D.R., J. Jeng. (2000). Assessing structure in the pleasure trip planning process. Tourism Analysis, 5 (1), 13-27.

Fuchs, G., A. Pizam. (2011). The importance of safety and security for tourism destinations. In Y. Wang, A. Pizam (Eds.), Destination marketing and management. Theories and applications (pp. 300-313). Wallingford, Oxfordshire, Cambridge, MA: CABI.

Fuchs, G., A. Reichel. (2006). Tourist destination risk perception: The case of Israel. Journal of Hospitality and Leisure Marketing, 14 (2), 83-108. doi: 10.1300/J150v14n02 06

Karl, M. (2017). Risiko und Tourismus Einfluss der Risikowahrnehmung auf den Destinationswahlprozess. Beiträge zur Wirtschaftsgeographie München 12.

Karl, M. (2018). Risk and uncertainty in travel decision-making - tourist and destination perspective. Journal of Travel Research, 57, 129-146. doi: 10.1177/004728751667 8337

Karl, M., C. Reintinger. (2016). Mapping Destination Choice: Set theory as a methodological tool to investigate tourists ' destination choice. In M. Kozak, N. Kozak (Eds.), Tourist Behaviour. An International Perspective (pp. 74-83). Wallingford, Boston: CABI.

Karl, M., C. Reintinger. (2017). Investigating tourists' destination choices: An application of network analysis. European Journal of Tourism Research, 15, 112-130.
Karl, M., C. Reintinger, J. Schmude. (2015). Reject or select: Mapping destination choice. Annals of Tourism Research, 54, 48-64. doi: 10.1016/j.annals.2015.06.003

Karl, M., J. Schmude. (2017). Understanding the role of risk (perception) in destination choice: A literature review and synthesis. Tourism: an interdisciplinary Journal, 65 (2), 138-155.

Karl, M., G. Winder, A. Bauer. (2016). Terrorism and tourism in Israel: Analysis of the temporal scale. Tourism Economics, 1-10. doi: 10.1177/1354816616686417

Mansfeld, Y. (1992). From motivation to actual travel. Annals of Tourism Research, 19 (3), 399-419. doi: 10.1016/01607383(92)90127-B

Reisinger, Y., F. Mavondo. (2005). Travel anxiety and intentions to travel internationally: Implications of travel risk perception. Journal of Travel Research, 43 (3), 212-225. doi: 10.1177/0047287504272017

Ryan, C. (1998). The travel career ladder: An Appraisal. Annals of Tourism Research, 25 (4), 936-957. doi: 10.1016/S01607383(98)00044-9

Sönmez, S.F., A.R. Graefe. (1998a). Influence of terrorism risk on foreign tourism decisions. Annals of Tourism Research, 25 (1), 112-144.

Sönmez, S.F., A.R. Graefe. (1998b). Determining future travel behavior from past travel experience and perceptions of risk and safety. Journal of Travel Research, 37 (2), 171-177. doi: 10.1177/004728759803700209

Um, S., J.L. Crompton. (1990). Attitude determinants in tourism destination choice. Annals of Tourism Research, 17 (3), 432448. doi: 10.1016/0160-7383(90)90008-F 